\title{
Neurology
}

\section{The Past 10 Years. And the Next.}

\author{
Robert C. Griggs, MD, Editor-in-Chief
}

Dr. John Noseworthy becomes Editor-in-Chief of Neurology on January 1, 2007. Dr. Noseworthy will introduce his editorship in the January 2nd issue of Neurology with an overview of planned changes and new developments in the Journal.

It has been a privilege to serve as Editor over the past 10 years. The many changes in publishing, in the specialty of neurology, and within the American Academy of Neurology (AAN) have provided the Journal with unprecedented opportunities for growth and development. It has been a team effort, and I am grateful to the many people who have contributed to its success.

Ten years ago, Neurology was a monthly journal published only in English and only in print. Neurology had not had international reviewers or Editorial Board members. Neurology is now twice-monthly in print, posts papers weekly online, and has established limited-circulation foreign language editions in Italian, Polish, Japanese, and Turkish. The Chinese, Spanish, and Korean editions will launch in January. Neurology now receives assistance from over 700 international reviewers, and $10 \%$ to $20 \%$ of the Editorial Board is internationally based. We also launched an International Newsletter, edited by Antonio Culebras, MD, that has covered international congresses and accomplishments of our colleagues overseas.

Neurology's venture into poetry, short stories, and other personal prose was initiated by David Goldblatt, MD, and is now in the "Reflections" section under Michael H. Brooke, MD. Judging by the number of submissions, correspondence, and comments, this section has been an overwhelming success. Similarly successful and with a devoted following is the Changes, People, and Comments section edited by Robert J. Joynt, MD, PhD.

The online journal. Neurology went online in 1999. All present and past content of Neurologysince its inception in 1951-will soon be available on line. The initial steps for Neurology's move online were championed and fostered by Michael $\mathrm{H}$. Brooke, MD. In 2000, Neurology moved to HighWire Press under the expert leadership of John Sack and Bill Witscher. We had several day-long consultations with them along with Tony Delamothe (Deputy Editor, $B M J$ ) and Kent Anderson (Executive Director, International Business \& Product Development,
$N E J M)$ that sparked many of the innovations that users of www.neurology.org currently enjoy. Some of the improvements include rapid posting of articles and correspondence, $\mathrm{CME}$, supplemental data, and video clips-now virtually required for all papers considering distinctive physical findings. Neurology's Patient Page and Resident and Fellows Section, two of the most popular sections, appear solely online.

Editorial Board. The Editorial Board of Neurology has been made up of an immensely talented and committed group of academic neurologists and neuroradiologists. The Editorial Board has shaped Neurology policy and has reviewed nearly half of all papers Neurology has published. The turnaround time is impressive-ranging from hours to a day or two-for reviews, advice, and other help. The "best" average time for one of our Editorial Board members is four hours-at a pace of one to three manuscripts per week.

Associate Editors. Neurology has had the benefit of expert and dedicated academic leaders as Associate Editors. University of Rochester Department of Neurology Associate Editors from 1997 to 2001 included Charles Duffy, MD, PhD; Leon Epstein, MD; and Karl Kieburtz, MD, MPH (figure 1). Serving as Associate Editors from 2002 to 2006 were Robert A. Gross, MD, PhD; Jonathan Mink, MD, PhD; Garrett Riggs, MD, PhD; and Steven R. Schwid, MD (figure 2 ). Their expertise has greatly contributed to the new features in Neurology. Two senior biostatisticians have served as Associate Editors and have done the lion's share of statistical reviews: Michael McDermott, $\mathrm{PhD}$ (1997-2002), and Richard Kryscio, PhD (2003-2006) (figure 3). Their thorough and detailed reviews have improved papers, mentored authors, educated other reviewers, and supported the Editor.

Neurology Editorial Office staff. The growth from receiving fewer than 2,000 manuscripts per year to handling nearly 5,000 per year has posed the immense challenge of sheer volume of work for the Editorial Office. The Editorial Office staff (figure 4) has handled the work flow with efficiency, accuracy, and courtesy. The majority of friendly mail received by the Editor refers to the helpfulness of staff. The team of Kathleen M. Pieper (Managing Editor, Neurology Online), Sharon Quimby (Senior Manuscript Editor), Sandi Moriarity (Manager, Editorial Office),

2110 Copyright (C) 2006 by AAN Enterprises, Inc. 

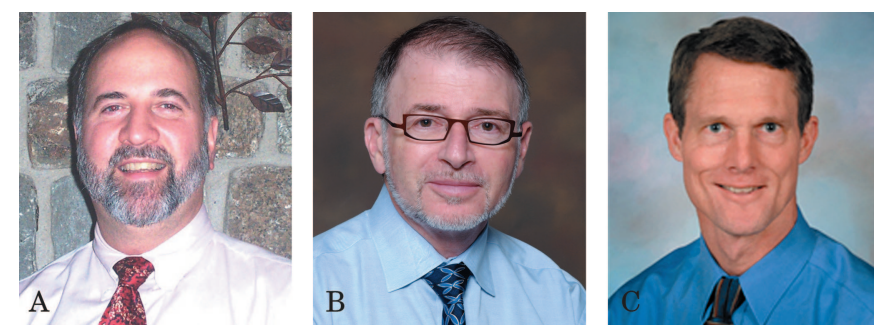

Figure 1. Left to right: Charles Duffy, MD, PhD; Leon Epstein, MD; Karl Kieburtz, MD, MPH.

and Morgan Serry (Editorial Associate) has provided dedicated support for the past 5 to 9 years.

Neurology sections. The additions to Neurology's table of contents have reflected the creativity and dedication of many talented leaders of our specialty. Associate Editor Clay Goodman, MD, established Neurology's Continuing Medical Education (CME) program. He single-handedly worked with the Editorial Office to prepare an exam for each issue of $\mathrm{Neu}$ rology. After 5 years, he was succeeded by Paul Schulz, MD, and Steven Lewis, MD. The CME program is heavily and increasingly used.

Neurology's monthly Patient Page has received the largest number of online "hits" and has been coedited by Robin Brey, MD, and Janet Jankowiak, MD. Karen Johnston, MD, MSc, initiated the Resident and Fellow Section, turning the reins over to Mitchell Elkind, MD, MS, in May 2006. The section is expanding steadily, with papers addressing important issues relative to training as well as highquality educational videos and other material.

Advice. Three senior academic leaders deserve specific mention. Previous Editor-in-Chief Robert B. Daroff, MD, has provided rapid (less than 24 hours) advice on a wide range of issues. Dr. Daroff's expertise and rigor prompted me to appoint him Scientific

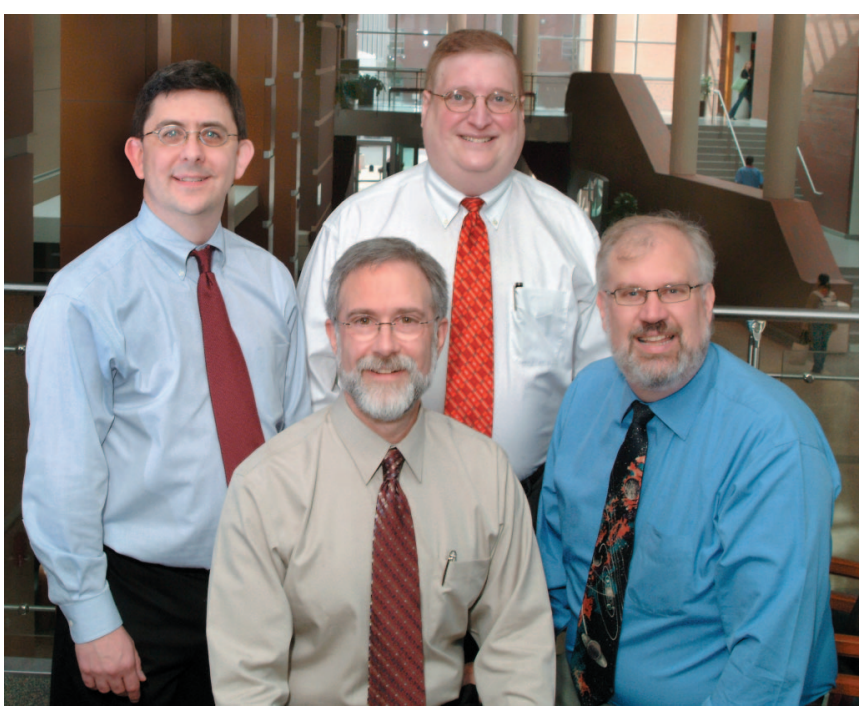

Figure 2. Seated left to right: Robert A. Gross, $M D, P h D$; Jonathan Mink, MD, PhD. Standing left to right: Garrett Riggs, MD, PhD; Steven Schwid, MD.
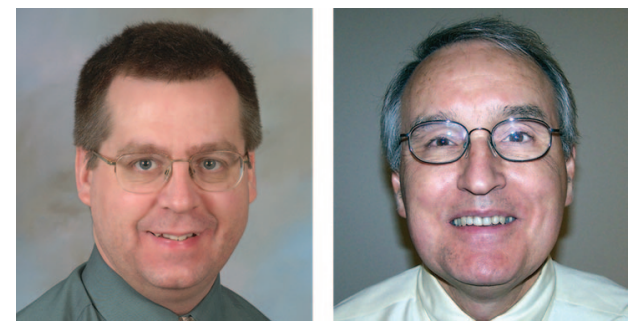

Figure 3. Left to right: Michael McDermott, PhD; Richard Kryscio, PhD.

Integrity Advisor, in which role he helps Neurology maintain the highest ethical standards.

Jack Whisnant, MD, has served as "Ombudsman"-Neurology's "Complaints Department." Dr. Whisnant has diplomatically fielded concerns and has given us wise advice on ways that the Editors and editorial staff can improve the responsiveness to authors' needs. Lewis P. Rowland, MD, Editor of Neurology Today and former Editor-in-Chief of Neurology, has provided consistent support, rapid reviews, and wise counsel.

Neurology and the AAN. Neurology is the Official Journal of the American Academy of Neurology. The Editor-in-Chief has had the unwavering support of the Academy-its Board of Directors and full-time administrative staff. The Editor-in-Chief sits on the AAN Board of Directors. In this role, I have had the opportunity to work with the leaders of our specialty. Each AAN President has exerted strong leadership and provided consistent support to Neurology: Ken Viste, MD; Steven Ringel, MD; Fran Kittredge, MD; Stanley Fahn, MD; Sandra Olson, MD; and Thomas Swift, MD. The AAN's General Counsel, Murray Sagsveen, has been a major asset, providing legal opinions, statements concerning ethical matters, and Neurology editorials. The Executive Director/CEO of the Academy, Catherine Rydell, has set a high standard for rapid and helpful AAN responses to journal-

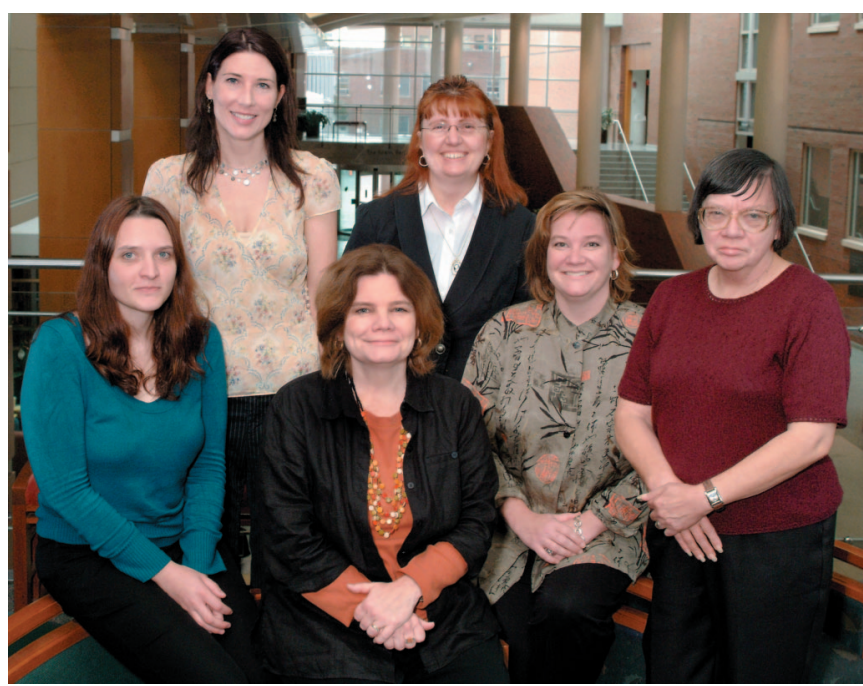

Figure 4. Front row left to right: Morgan Serry, Patricia Goodman, Kathy Pieper, Pat Pattison. Back row left to right: Sharon Quimby, Sandi Moriarity. 
related matters. The decision to move Neurology under the AAN's for-profit entity, American Academy of Neurology Enterprises, Inc. (AEI), provided the opportunity to work with an outstanding CEO, Bruce Polsky, as well as the distinguished Board of AEI.

The publisher. Neurology moved to LippincottRaven just as I was taking over as Editor-in-Chief. Lippincott-Raven became Lippincott Williams \& Wilkins in 1998. Particularly noteworthy was Nancy Megley, Senior Publisher, whose experience was a major resource. More recently, Senior Publisher David Marshall has exerted strong leadership in adapting to the rapid changes in journal publishing. Senior Production Editor Alexandra Lazerow and her team have provided imaginative, consistent, and flawless assistance in journal processing and publication.

Being Editor-in-Chief has been fun and rewarding. The job has given me the opportunity to meet and work with hundreds of neurologists both in the US and abroad. My own enjoyment of the editorship has been fostered and supported by my wife,
Rosalyne H. Griggs. She and my daughters, Jennifer and Heather, have been unwavering in their support and encouragement as the magnitude and scope of Neurology has expanded.

The next editor. As current Editor-in-Chief, I did not participate in the selection decision for the next Editor-in-Chief. However, if I had, I would have hoped to be able to lure Dr. John Noseworthy into accepting the position. Dr. Noseworthy is an internationally renowned academic neurologist as well as a leader of the American Academy of Neurology. He was Chair of Neurology of the Mayo Clinic until early 2006 and is now Medical Director for Development at Mayo. He served as Chair of the Science Committee of the American Academy of Neurology for the past 4 years. Dr. Noseworthy has served on the Neurology Editorial Board since 1997. He has extensive experience as a clinical investigator with a focus on multiple sclerosis. His textbook, Neurological Therapeutics: Principles and Practice, just entering its second edition, defines our specialty.

The future of Neurology is in good hands.

Associate Editors' Note: Those of us who worked closely with Dr. Griggs for the past several years wish to add a few comments of our own, recognizing that our statements will be correctly viewed as being hopelessly biased. We are, we disclose, ardent fans of our erstwhile Editor-in-Chief, and intensely loyal. This, perhaps, says more about his leadership than anything else. We wish him well in his "retirement" from Editorial duties. We can only wonder what additional accomplishments will accrue as a result of all those "free" hours. Our confidence is high that his wife, children, and grandchildren are pleased at the prospect. As will be opera houses around the world. Further, we are grateful for the opportunity to have joined with him in service to our readers. Our editorial work has been (mostly) highly enjoyable and in this we owe a huge debt to our mentor: his freely flowing ideas and equal willingness to hear from us, even if in contradiction; tutelage in wielding the Editorial Orb and Scepter (Neurology 2006;66:153); and, importantly, trust in our editorial opinions and growth. It may be obvious to say that we could not have done this without Dr. Griggs- he offered us the positions, after all. But it is especially true that we could not have done as well as we did without his interest, guidance, and support. Our thanks, Berch.

Robert A. Gross, Jonathan W. Mink, Garret H. Riggs, Steven R. Schwid 


\title{
Neurology
}

\author{
Neurology : The Past 10 Years. And the Next. \\ Robert C. Griggs \\ Neurology 2006;67;2110-2112 \\ DOI 10.1212/01.wnl.0000252246.16716.f8
}

This information is current as of December 26, 2006

\section{Updated Information \&}

Services

Permissions \& Licensing

Reprints including high resolution figures, can be found at: http://n.neurology.org/content/67/12/2110.full

Information about reproducing this article in parts (figures,tables) or in its entirety can be found online at:

http://www.neurology.org/about/about_the_journal\#permissions

Information about ordering reprints can be found online:

http://n.neurology.org/subscribers/advertise

Neurology ${ }^{\circledR}$ is the official journal of the American Academy of Neurology. Published continuously since 1951, it is now a weekly with 48 issues per year. Copyright . All rights reserved. Print ISSN: 0028-3878. Online ISSN: 1526-632X.

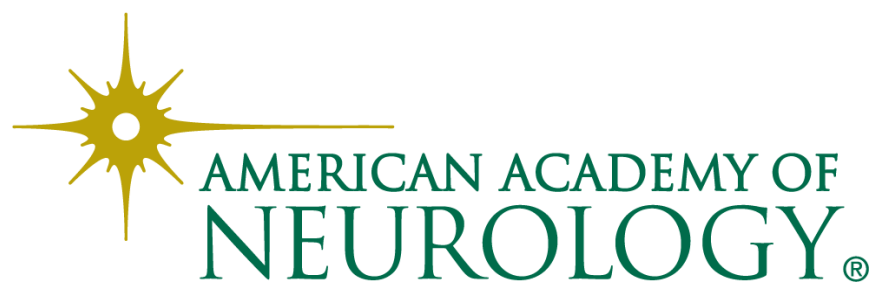

